Shu, M., \& Scott, N. (2014). Influence of Social Media on Chinese Students' choice of an Overseas Study Destination: An Information Adoption Model Perspective. Journal of Travel and Tourism Marketing, 31(2), $286-302$.

\title{
INFLUENCE OF SOCIAL MEDIA ON CHINESE STUDENTS'CHOICE OF AN OVERSEAS STUDY DESTINATION: AN INFORMATION ADOPTION MODEL PERSPECTIVE
}

\section{Mengya (Lavender) Shu and Noel Scott The School of Tourism, The University of Queensland.}

\section{RUNNING HEAD: INFLUENCE OF SOCIAL MEDIA}

\begin{abstract}
This study is an experimental investigation of the influence of social media on choosing an overseas study destination. The elaboration likelihood model of communication and persuasion provides a conceptual basis for this study. Data was collected through convenience sampling of Chinese students from three Brisbane tertiary institutions. Participants were provided with one of the four treatments with manipulated stimuli. Results suggest that social media content is an influential factor in determining destination attractiveness, and may, if correctly specified, facilitate high elaboration and generate corresponding positive or negative impressions of the study destination from students.
\end{abstract}

KEYWORDS: Educational tourism, electronic word of mouth (eWOM), persuasion, social media, China, elaboration likelihood model, information adoption model

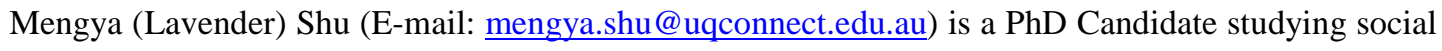
media and tourism and Dr Noel Scott (E-mail: noel.scott@uq.edu.au) is Associate Professor in the School of Tourism at The University of Queensland, St Lucia, Brisbane, Queensland, Australia. He has over 170 published academic contributions and has conducted tourism projects in numerous overseas countries. 


\title{
INFLUENCE OF SOCIAL MEDIA ON CHINESE STUDENTS'CHOICE OF AN OVERSEAS STUDY DESTINATION: AN INFORMATION ADOPTION MODEL PERSPECTIVE
}

\author{
RUNNING HEAD: INFLUENCE OF SOCIAL MEDIA
}

\begin{abstract}
This study is an experimental investigation of the influence of social media on choosing an overseas study destination. The elaboration likelihood model of communication and persuasion provides a conceptual basis for this study. Data was collected through convenience sampling of Chinese students from three Brisbane tertiary institutions. Participants were provided with one of the four treatments with manipulated stimuli. Results suggest that social media content is an influential factor in determining destination attractiveness, and may, if correctly specified, facilitate high elaboration and generate corresponding positive or negative impressions of the study destination from students.
\end{abstract}

KEYWORDS: Educational tourism, electronic word of mouth (eWOM), persuasion, social media, China, elaboration likelihood model, information adoption model 


\section{INTRODUCTION}

Social media is "a variety of technology and software built on the foundation of Web 2.0 that allows exchange and creation of User Generated Content (UGC)” (Kaplan \& Haenlein, 2010, p. 61). A social media site involves a variety of online sources of information that are created from the 'bottom-up' with the intention of informing others about products, services, issues, and/or brands. Social media can be used for marketing purposes as a type of third party persuasion technique, and is becoming increasingly popular. A potential traveler's use of social media can influence his/her purchasing decisions during the travel information-gathering phase, as well as impact on the user's perception of tourist destination attractiveness (Cheung, Lee, \& Rabjohn, 2008; Cheung \& Thadani, 2010; Chu \& Kamal, 2008; Zhu \& Tan, 2007).

Social media as a type of persuasion has been studied using both the Elaboration Likelihood Model (ELM) and Information Adoption Model (IAM). The ELM can be used to determine the effectiveness of different social media material, while IAM, as an updated version of the ELM model, simplifies identification of the determinants of the persuasion process in a focused context. IAM can be used to determine the effectiveness of stimulus material used in the social media persuasion process (Chu \& Kamal, 2008; Tam \& Ho, 2005).Although ELM and IAM were developed over two decades ago and have been used extensively in other contexts (Douglas, Kiewitz, Martinko, Harvey, Kim, \& Chun, 2008; Flynn, Worden, Bunn, Connolly, \& Dorwaldt, 2011; Nussbaum, 2006), they have not been used to study the influence of social media on education tourism choices. In tourism, the ELM and IAM models have been used to examine the effectiveness of a destination website, but not the effectiveness of social media (Cheung, Lee, \& Rabjohn, 2008; Cheung \& Thadani, 2010; Chu \& Kamal, 2008).

In China, Internet users have been active in adopting social media platforms, especially homegrown ones. These domestic social media platforms differ from Western platforms in many ways. Thus, to learn how Chinese consumers use social media, overseas companies need to take advantage of these platforms. Restrictions on use of Western websites and social media have resulted in an extensive, homegrown, state-approved digital ecosystem in which Chinese-owned sites thrive. Facebook, YouTube, and Twitter are banned in China, but their Chinese equivalents are expanding. By some measures, usage of Chinese social media is the most intense in the world. 
Chinese Internet users are online for an average of 2.7 hours per day, considerably more than for other developing countries and on par with usage patterns in Japan and the United States. China also has the most complicated social media landscape and the largest user base in the world (Crampton, 2011). Hence, China social media provides a useful context for this study.

While educational travel marketing and tourism marketing are considered to be two separate markets, the growth of these two industries in recent decades has drawn increased recognition of both their economic and social significance. A convergence between the two markets is also evident, with education that facilitates mobility and learning becoming a growing part of the tourist experience. Thus, educational tourism is a term described by Ritchie, Carr and Cooper (2003) as:

$$
\begin{aligned}
& \text {... tourist activity undertaken by those who are undertaking an overnight } \\
& \text { vacation and those who are undertaking an excursion for whom education } \\
& \text { and learning is a primary or secondary part of their trip. This can include } \\
& \text { general educational tourism and adult study tours, international and } \\
& \text { domestic university and school students (p.18). }
\end{aligned}
$$

To date, however, little research has been conducted on educational tourism, and the industry is unaware of the real size of this segment. Hence, there are many areas that require empirical examination to address links between education and tourism (Ritchie, Carr, \& Cooper, 2003; Wang \& Li, 2008).

This study explores how social media content influences destination attractiveness in the early travel decision-making stage. As mentioned above, education tourism provides the context for this study, and Chinese outbound students at Australian universities are the target group. This study aims to determine whether argument quality or source credibility of the social media material is the major determinant of destination attractiveness.

\section{LITERATURE REVIEW}

\section{Social Media's Hybrid Role in Marketing and Promotion}


Social media, as a new phenomenon for most enterprises, is changing the ways of communicating with customers significantly. The $21^{\text {st }}$ century is witnessing an explosion of messages transmitted through Internet-based platforms such as social media, providing a major influence on all aspects of tourist behavior, including destination awareness, information searching and acquisition, opinions and attitudes towards a product or service, intentions of purchasing, and post-trip evaluation (Chan \& Guillet, 2011). However, very little research has been carried out to provide guidance for marketing managers on how to integrate social media into their marketing communications. Consequently, many tourism managers lack a full appreciation of social media's changing role in the marketing strategy, and methods for shaping the new type of consumer-to-consumer conversations are not well understood(Boone \& Kurtz, 2007).

Social media such as Facebook and blogs may be used by companies to communicate with customers in a similar way to other forms of media and, in addition, customers may also utilize it to communicate with each other (O’Connor, 2008; Rodgers \& Sheldon, 2002).This second mode of use is an extension of traditional WOM; however, instead of communicating only with friends or family, a person can share their experiences or opinions with hundreds or thousands of people in a few clicks. Consumer-to-consumer communication empowers travelers by providing easier access to information and control over their media consumption, unlike traditional promotional methods where companies have only limited control over what and how travelers communicate online (Singh, Verson-Jackson, \& Cullinane, 2008). These social media messages affect tourist behavior; thus, marketing managers should incorporate social media into their company's integrated marketing communication strategies (Li \& Bernoff, 2008; Mangold \& Faulds, 2009; Ramsey, 2006).Critically, while business cannot directly control the transmitted messages, they can influence the conversations (Chan \& Guillet, 2011; Gillin, 2007).

\section{Social Media's Impacts on Tourist Behavior}

Although the importance of social media for tourism has been discussed extensively, most studies relate to a specific form (such as blogs) or a particular online travel community (Chung \& Buhalis, 2008; Hsu \& Lin, 2008; Park, Lee, \& Han, 2007; Wang \& Fesenmaier, 2004b).Previous studies have examined tourists' intentions to use social media and how travelers upload photos 
and videos, comment on others' blog posts, and provide feedback on a trip (Lee, Law, \& Murphy, 2011), as well as travelers' motivations in making use of the technologies, and their intentions in terms of encouraging friends and families to use social media (Dasgupta, Granger, \& Mcgarry, 2002; Hsu \& Lin, 2008; Wang \& Fesenmaier, 2004a). However, there is a lack of research on how social media portals influence travelers, and how this can be made more effective (Crompvoets, Rajabifard, Bregt, \& Williamson, 2004; Lee, Law, \& Murphy, 2011).

\section{Concept and Theory of Persuasion}

In order to address the research gap, it is necessary to ground social media in theory. Hence, the concept of persuasion is used as the theoretical base of this paper. While there are multiple definitions of persuasion as shown in Table 1, five core aspects have been identified (Anderson, 1971; Bettinghaus \& Cody, 1987; O’Keefe, 1990; Smith, 1982). Firstly, persuasion is a purposive attempt to influence others. From the time of the ancient Greeks, rhetoric (or persuasive communication) has been seen as a means of deliberately influencing another's attitude or behavior that scholars should be aware of and able to use (Bettinghaus \& Cody, 1987). Hence, persuasion is an exercise in influence and, therefore, power - the means to affect the attitudes or actions of another (Wrong, 1979). Secondly, unlike other forms of power such as force or manipulation, persuasion involves free choice. Thus, thirdly, successful persuasion is self-persuasion and persuadees alter their attitude or subsequent behavior on their own volition as a result of the communication (O’Keefe, 2002). Fourthly, persuasion involves transmission of a message. Persuasion is a type of communication, and the message is a primary component of such activity. The message consists of both arguments and simple cues and can be delivered through a variety of methods (i.e., Internet, mass media, interpersonal communication), and be verbal or nonverbal (Larson, 2010). Finally, persuasion is also a symbolic process and hence deals with symbols, that is, messages with rich meanings involving words, images, and nonverbal signs. A communicator is able to harness these symbols to accomplish the goal of persuasive communication. Based on these five elements a more comprehensive definition of persuasion can be extracted, that is, it is "a symbolic process in which communicators try to convince other people to change their attitudes or behavior regarding an issue through the transmission of a message, in an atmosphere of free choice” (Perloff, 2003, p.8). 


\section{Insert Table 1 around here}

Within the field of psychology, a number of models have been developed to explain attitude formation and change in a persuasive setting, among which the ELM is the most widely recognized and accepted (Ham, Weiler, Hughes, Brown, Curtis, \& Poll, 2008). ELM has been described as the most promising theory of persuasion and attitude change, as it integrates an array of variables and explains why and how messages are more or less likely to lead to certain outcomes (Song, 2008).

Developed by Petty, Cacioppo and Schumann (1983), ELM is a dual-process model that deals with the social information processing phenomena. It is based on the idea that persuadees vary in the extent to which they are willing to engage in elaboration of the persuasive issue.' Likelihood' is the probability that an event can occur, and is used to illustrate whether the elaboration is likely or unlikely (Perloff, 2003). The term 'elaboration' is defined as 'the extent to which the individuals engage in information contained in the communication, and mentally modify or process the issue" (Perloff, 2003, p.138), and relates to people's issue-relevant thinking. When receivers engage in highly issue-relevant thinking, they will attend closely to the persuasive message, carefully synthesize the arguments, and reflect on personal interest and considerations. On the other hand, when receivers passively engage in a conversation and receive a message, there is little elaboration and issue-relevant processing. ELM suggests that persuadees' degree of elaboration forms a spectrum, in which the extent of issue-relevant thinking varies from little or none to extremely high. Persuasion can take place at any point of this elaboration continuum; however, the nature of the process varies with the degree of elaboration (Tam \& Ho, 2005; Yang, Hung, Sung, \& Farn, 2006).

In order to distinguish differences in the persuasion process, ELM stipulates that there are two distinct routes or ways of processing the thoughts and reactions resulting from messages (Perloff, 2003), that is, the 'central route' and the 'peripheral route'. The central route (on the left of Figure 1) is characterized by significant issue-relevant thinking when elaboration is high. This happens when individuals undertake the cognitive effort to examine and evaluate arguments presented, relate them to their own values and prior experiences, and link them with other issue- 
relevant material (Petty, Cacioppo, \& Schumann, 1983). Thus, the results of persuasion are closely associated with the receiver's thoughtful considerations of arguments (Petty \& Krosnick, 1995). To achieve this, the person must be initially motivated to process a message. Three main motivational factors are personal relevance of the message, personal mood, and need for cognition (Petty, Schumann, Richman, \& Strathman, 1993). Receivers also need to have the ability to process the message. Factors that influence the ability to engage in the issue-relevant thinking include message repetition, the receiver's body posture, the existence of distractions during the communication, and the receiver's existing knowledge (Petty \& Cacioppo, 1986; Wood \& Kallgren, 1988). Attitudes changed through the central route are well integrated into the receiver's belief structure and have a more integrated cognitive structure. This suggests that these attitudes are predictive, enduring, and tend to be relatively resistant to change.

Although attitude change is the most desirable outcome of persuasive communication, it is hard to achieve because it requires the receiver to be motivated as well as able to elaborate the arguments. Given the difficulties of changing people's beliefs via the central route, the peripheral route may be chosen as an alternative persuasion strategy (Tang, Jang, \& Morrison, 2012). ELM holds that persuasion does not always need a high level of elaboration and effortful issuerelevant thinking; instead, attitude change may occur via a peripheral route when simple cues influence the attitudes. As shown in Figure 1, when the receiver is not sufficiently motivated to process information, the peripheral route may be taken if simple cues such as expertise of the source and source attractiveness trigger heuristic inference. These heuristic principles require less elaboration and information processing for simple decision formation; thus, extrinsic features of the communication are usually activated. Although an array of heuristic principles has been suggested in the literature, three are discussed more extensively: credibility of communicator; liking the message; and consensus (if other people believe it, then it's probably true) (Bhattacherjee \& Sanford, 2006; Wood \& Kallgren, 1988). While the peripheral route can be effective in the short term, people's feeling about source attractiveness and source expertise tend to change over time, and these factors may gradually undermine the formulated attitude. Therefore, attitude changes based on peripheral cues are less predictable and less persistent in the face of other conflicting messages (Morris, Woo, \& Singh, 2005; Perloff, 2003). 
Thus, ELM indicates that both central and peripheral routes lead to persuasion, but that attitude change via the peripheral route is short-lived compared to that of the central route. However, it might last long enough to cause immediate behavior, such as voting for a candidate or purchasing a product (Ham et al., 2008). Given this, it is necessary to determine the impact of different intentions on attitude or behavioral change in a specific circumstance. ELM indicates that two major factors determine the route that results from a persuasive message: argument strength (also known as argument quality); and credibility of source. A message with high argument strength heads toward the central route, while credibility of source leads to the peripheral route. Based on these two elements, a more recent model, IAM, was proposed specifically for a computer-mediated communication context (O’Keefe, 2002).

\section{Insert Figure 1: Elaboration likelihood model about here}

\section{Information Adoption Model (IAM)}

In eWOM and ordinary online information sharing, the effect of information on each person varies; the same message may generate very different outcomes from recipients due to their previous experience, beliefs, and perceptions (Chaiken \& Eagly, 1976). Based on ELM, Sussman and Siegal (2003) incorporated a dual process theory and proposed that IAM could explain how people are influenced in a computer-mediated communication context. The two routes posited by ELM that impact on attitude change, that is, central and peripheral, are also found in IAM. That is, the central route emphasizes the nature of the arguments, while the peripheral route refers to issues that are not directly related to the subject (Petty \& Cacioppo, 1986). IAM, then, is based on the proposition that argument quality has a central influence, and source credibility is a peripheral cue in information adoption (Sussman \& Siegal, 2003) as shown in Figure 2.

The importance of these two elements has been validated in numerous research studies (Davy, 2006; Hong, 2006; Sundar, Knobloch-Westerwick, \& Hastall, 2007; Zhang \& Watts, 2003). Argument quality in information system research refers to the persuasive strength embedded in the message, and end-users' perceptions of the value of the produced output. Applied to the context of computer-mediated communication, argument quality is assessed on its content, accuracy format, and timeliness (Bhattacherjee \& Stanford, 2006; DeLone \& McLean, 2003; 
Negash, Ryan, \& Igbaria, 2002).Source credibility refers to the message receiver's perception of the credibility of a source, but has no reflections of the message itself (Chaiken, 1980). Rather, it is the extent to which content is perceived to be trustworthy and competent. Sources with higher credibility will be believed to be reliable and useful, and this will facilitate better information adoption (Eagly \& Chaiken, 1993; Ko, Kirsch, \& King, 2005; Petty \& Cacioppo, 1986). As indicated in Figure 2, argument quality and source credibility are the main determinants of information adoption, and are categorized as 'strong' or 'weak' to investigate how social media material can influence perceived destination attractiveness.

\section{Insert Figure 2 about here}

\section{METHODOLOGY}

This research uses a quasi-experimental design. Subjects were randomly assigned to one of the four conditions in a 2 (argument quality: strong versus weak) by2 (source credibility: high versus low) factorial between-participants experiment. The main aim of this project is to explore the most influential factor in social media content; thus, argument quality and source credibility are measured as strong or weak. Four conditions of the treatment of stimulus material are abbreviated as: high source credibility (HSC) with high argument quality (HAQ); high source credibility (HSC) with low argument quality (LAQ); low source credibility (LSC) with high argument quality (HAQ); and low source credibility (LSC) with low argument quality (LAQ) (Table 2). Respondents were randomly assigned to one of four distinctive treatments of the stimulus material (Baker, 2001; Campbell \& Stanley, 1966).

\section{Insert Table 2 about here}

Hypotheses are proposed as below:

H1 Argument quality (AQ) has an effect on perceived destination attractiveness (DA) H2 - Source credibility (SC) has an effect on perceived destination attractiveness (DA) 


\section{Procedures to test hypotheses}

In order to conclude that $\mathrm{H} 1$ is supported, the following two conditions need to be fulfilled:

DA of treatment 1 is the highest in treatments $1,2,4$

DA of treatment 4 is the lowest in treatments $1,3,4$

In order to conclude that H2 is supported, the following two conditions need to be fulfilled:

DA of treatment 1 is the highest in treatments $1,3,4$

DA of treatment 4 is the lowest in treatments 1, 2, 4

Table 3 shows the operationalization of concepts, ideas, and measurement scales used in previous literature with similar research aims. Source credibility is defined as "information sender is willing to give honest and fair content with relevant expertise” (Choi \& Rifon, 2002, p.17).In this study, a six-item, seven-point semantic differential scale used in previous studies was adopted. In studies by Choi and Rifon (2002), and Priester and Petty (1995, 2003), the items that were used to measure source credibility are: trustworthy, experienced, expertise, and reputable. The treatment source credibility was measured using website and author credibility as both are important for third-party messages (Chu \& Kamal, 2008).

Argument quality describes the persuasive strength embedded in the message, namely, whether it generates positive or negative elaboration. For argument quality, four items are used in this study based on previous studies by Petty and Cacioppo (1986), and Coulter and Punj (2004), that is, relevance, pleasant, convincing, and useful. The dependent variable of this study is perceived destination attractiveness, or the respondent's attitude towards a destination. Previous studies (Cheung et al., 2008; Chu \& Kamal, 2008; MacKenzie \& Lutz, 1989) used questions such as those that queried attitudes towards a brand or a product. In this current study, participants' perceptions of a study destination will be sought; hence, the dependable variable is perceived destination attractiveness, and the items used are good, attractive, favorable, and intent to go. To further assure that the results are reliable, a negative question was also asked to assess if participants think the destination is a bad place to study. Hence, 13 scale items were used in a pilot test for this study; all of them applying a seven-point Likert scale, with 1-7 representing a 
continuum of strongly disagree to strongly agree (Kumar, 2010). Demographic information was also collected to determine the sample characteristics (Alreck \& Settle, 1985).

\section{Insert Table 3 about here}

\section{Stimulus Material Development}

A mock-up content approach was chosen for this particular study. Two types of social media platforms were incorporated into the stimulus material design.

\section{Insert Figure 3 about here}

Figure 3 illustrates the four components of the stimulus material. The upper part of Figure 3 shows the interpretation of source credibility with a description of the source site and information creator. The lower part shown in Figure 3 is the stimulus material describing argument quality. Tables 4 and 5 show details of how treatment of source credibility is operationalized. Images are also attached to provide visual impressions of Country A. For the sake of better understanding and to eliminate potential language barriers, the whole survey was designed in a bilingual format, that is, both English and Mandarin Chinese. All of the included elements were tested in a pilot test. Table 6 depicts further details how different treatments were operationalized for argument quality.

\section{Insert Table 4 about here \\ Insert Table 5 about here \\ Insert Table 6 about here}

\section{Pilot Test}

A pilot test was conducted to test the validity of stimulus material and survey questionnaire. As the first study involved a special culture group, it was essential to ensure the most appropriate scales were incorporated into the experimental design. The initial survey was distributed to15 Chinese students who were invited to read one of the four treatments of stimulus material. They were then asked questions to gather their impressions of the given information. Based on the 
feedbacks, orders of some questions were rearranged, and the format of the mock-up BBS and blog was slightly changed. As a result, a total of 13 items were used in the official survey.

\section{Sampling and Experiment Procedures}

Chinese students in Brisbane were the respondents for this study. As they already had experience in choosing an overseas study destination, these students were considered as a cohort that fitted the research aim. Students from The University of Queensland (UQ), Griffith University (GU), and Queensland Institute of Business and Technology (QIBT) were approached face-to-face to ensure a comprehensive sample. In addition, lecturers at the three institutions were approached via email to explain the aim and the experimental design of the study. After a brief description of the research, surveys were distributed to all the Chinese students in particular classes at the three universities who had agreed to participate in the study. Each respondent received a small incentive (a pen with The University of Queensland logo) to encourage participation.

A total of 236 students participated in the experiment and were randomly allocated to one of the four different treatments of stimulus materials (59 to each treatment). Of the original 236 studies completed, 232 were included in the final sample after eliminating any incomplete studies (58 valid responses in each treatment).

\section{RESULTS}

\section{Profile of the Sample}

All respondents were of Chinese nationality. The majority of respondents (83.6\%) were aged 1824 with the remainder in the above 24age group. There were more female respondents (60\% of the total sample) than male (40\%), and most had been in Australia for up to two years (77.6\% of the total sample). The remaining 22.4\% of the students had been in Australia for more than two years. In order to achieve a diversified educational background, the researcher approached a variety of classes. More than 93.5\% of the respondents were working toward a diploma, undergraduate, or postgraduate degree, while only two respondents $(0.9 \%)$ were working toward research degrees. Respondents who were studying language courses comprised 6.5\% of the sample. 


\section{Manipulation Checks}

Table 7 shows mean scores of source credibility (SC), argument quality (AQ), and destination attractiveness (DA) based on four different treatments. For source credibility, the first two treatments have higher mean scores than the other two. It is therefore aligned with the original manipulation design, as the first two treatments have higher source credibility.

Similar to source credibility, scores of the four items of the argument quality scale were added and termed 'total argument quality' (Total AQ). The third column in Table 7compares the means of argument quality based on four treatments. The first and third treatments have higher mean scores than the others. This aligns with the original manipulation design, that is, the first and third treatments have higher argument quality.

\section{Hypotheses Testing}

To test the hypotheses, descriptive analysis, between-participants analysis of variance (two-way ANOVA), and correlation analysis are performed.

Scores of five items in the dimension of perceived destination attractiveness are calculated as a sum (DA total). The fourth column of Table 7 shows the result of comparing the DA total means of four treatments. It is interesting that the first and third treatments have much higher scores on perceived destination attractiveness; the difference is approximately 20.5\%. These two treatments have distinctive levels source credibility but the same high argument quality, and the mean scores of DA total are very close. Therefore, the conclusion can be drawn that argument quality is more influential than source credibility, namely, social media stimulus material will leave a favorable impression on viewers if it has higher argument quality.

\section{Insert Table 7 about here}

Table 8 details whether there are significant mean differences between groups for the two independent variables, SC and $\mathrm{AQ}$, and for their interaction, SC * AQ. The results suggest that there are significant differences between argument quality levels $(\mathrm{p}=0.000)$. Comparatively, no 
significant differences are detected in perceived destination attractiveness between source credibility $(\mathrm{p}=0.579)$ and the SC * AQ interaction $(\mathrm{p}=0.702)$.

\section{Insert Table 8 about here}

The following plot (Figure 4) provides a graphical illustration of the ANOVA results. DA changes correspondently when the level of argument quality is altered, but does not change in the case of source credibility. The two lines are roughly parallel which means that there is no evidence of an interaction, and the fact that they run closely together suggests that SC has little effect on DA.

To confirm our finds and further investigate the strength of the relationships between AQ, SC and DA, we also conducted bivariate correlations.

Table 9 shows the correlation between source credibility and perceived destination attractiveness. The correlation indicates the strength, and in this case it is 0.264.Therefore, the correlation between these two variables is very weak. A correlation of 0.264 would account for only $7 \%$ of variance between source credibility and perceived destination attractiveness, a small amount. This means $93 \%$ of variance is unaccounted for. Although weak, the direction of the relationship is positive. Overall, there is insufficient evidence to suggest any relationship between source credibility and perceived destination attractiveness.

\section{Insert Table 9 about here}

Table 10 shows the correlation between argument quality and perceived destination attractiveness. Pearson correlation indicates the strength, and in this case it is 0.731.Therefore, the correlation between these two variables is strong. A correlation of 0.731 accounts for $54.3 \%$

of variance between argument quality and perceived destination attractiveness. Moreover, the direction of the relationship is positive. Overall, there is sufficient evidence to suggest a strong relationship between source credibility and perceived destination attractiveness. 


\section{Insert Table 10 about here}

Based on the results discussed above, DA of treatment 1 is the highest in treatments 1,2, and 4, and DA of treatment 4 is the lowest in treatments 1,3,and 4 (Table 7). Strong correlation is detected between AQ and DA; however, no significant effect is found between SC and DA, nor in the $\mathrm{SC} * \mathrm{AQ}$ interaction.

Hence, the arguments presented in the stimulus material contribute significantly to the reader's perceptions of the potential study destination. Thus, while H1 is supported, H2 is rejected.

\section{DISCUSSION AND CONCLUSION}

The purpose of this study is to determine whether argument quality or source credibility of social media material is the major determinant of destination attractiveness, and to establish the persuasion route that is most frequently used by Chinese students when choosing a study destination. The results indicate that the destination is perceived more favorably when the social media content possess higher argument quality. Interestingly, when the social media content has higher argument quality and source credibility, the overall perceived destination attractiveness is not significantly higher. On the other hand, when social media content has low argument quality, the majority of respondents expressed that they gained an unfavorable impression towards the potential study destination. Similarly, manipulating the level of source credibility did not affect

the attractiveness of the potential study destination. Two-way ANOVA test also confirms the results from the descriptive analysis, in that significant main effects are shown for argument quality and perceived destination attractiveness, while very minor interaction effects are found for argument quality and source credibility. Therefore, the results indicate that AQ has a stronger influence than SC on perceived destination attractiveness. Correlation analyses were conducted to explore the strength of these relationships. As shown in Table 12, on the one hand, the value of the Pearson correlation coefficient (0.264) indicates a very weak relationship between source 
credibility and perceived destination attractiveness, while on the other hand, argument quality has a salient role in social media persuasion. The Pearson correlation coefficient for the relationship between argument quality and destination attraction (0.731) indicates a strong relationship. The conclusion drawn is that the nature of the argument (argument quality) presented in social media is associated with subsequent perceptions of a destination, while the trustworthiness of the source is not associated with people's perceptions of the destination. Thus, applying this to the given context, it is empirically supported that the persuasiveness of the presented social media messages is salient to outbound Chinese students when looking for an overseas study destination, and more effective if the central route of ELM is stimulated.

The results of this study show that the characteristics of the messages have a strong and significant impact on consumer decision to adopt online information. Of the four experimental treatments, the lowest mean score for destination attractiveness is associated with weak argument quality, regardless of whether source credibility is high or low. After examining the results for sub-scale items from argument quality, it can be seen that the relevance, usefulness, and comprehensiveness of the information are associated with viewers' better impressions of the destination. This is in line with extant literature on the impact of communication source, which found that people will be more highly involved with information that is comprehensive, relevant, and useful in fulfilling their search intentions, and will affect purchasing decisions (Cheung et al., 2008; Tam \& Ho, 2005; Tang et al., 2012).

The rejection of H2, H2a, and H2b indicates that Chinese students do not rely on perceived trustworthiness of the information site and information sender when deciding on an overseas study destination. This does not mean that they did not notice the difference, rather, the source credibility contributes little to persuasion and attitude change. The very low correlation coefficient discussed in Table 12further confirms the conclusion that source credibility is not strongly correlated with destination attractiveness. Given this, the peripheral route is not an option for this type of persuasive communication, and does not play a salient role in influencing online information adoption (Cheung et al., 2008). This conflicts with some findings of existing literature. Chu and Kamal (2008) found brand attitude index has the lowest mean among participants in the high trustworthiness and weak argument condition, which means that they 
believe consumers will suspect brand information from social media when considering a brand choice (Kale, Karandikar, Kolari, Java, Finin, \& Joshi, 2007), and are likely to trust information on a professional review website or a corporate website. Tam and Ho (2005) also agreed that peripheral variables could exert significant effects on web-users. These authors claimed that source credibility does not act as a factor that independently influences brand attitude formulation; instead, they found that trustworthiness affects the extent of elaboration and can be leveraged by the level of argument quality. These findings are not in line with this study's results, as a very weak correlation was found here between source credibility and perceived destination attractiveness, and between source credibility and argument quality. However, the differences found may be due to the given topic, that is, choosing a study destination. This is a decision that involves high perceived risk; thus, participants are highly motivated to scrutinize the information, engage in high cognition and elaboration with the content, but do not rely on source credibility as a peripheral cue.

This study provides insights into how students process social media information, and can assist institutions to better understand the phenomenon and develop effective communication strategies. These strategies would have two priorities. First, ensure that the messages do not reveal commercial purposes, that the messages are authentic, and that they are posted by third parties. Second, ensure that the persuasive strengths of the message are strong, as the merit of the argument is the single most influential factor related to destination attractiveness. A feasible strategy would be to have current students as ambassadors for the institution, recording their real-life experiences in a way that provides a sense of familiarity and empathy for potential overseas students. While these current students are not experts in the education area and therefore do not exert credibility, they would be perceived as trustworthy as a non-commercial third-party. Hence, their role as ambassadors for the institution could generate positive feedback and facilitate favorable impressions.

While the current study deals with education tourism, its findings are readily applicable to the broad scope of tourism, and even the business environment. Integrating social media as a platform for third-party marketing to encourage eWOM is a complicated issue and requires the consideration of several factors. Firstly, it should clearly identify the needs of the target market, 
which means proper market research needs to be undertaken to determine which persuasive route is most popular in the marketplace. Secondly, it should address high elaboration and issuerelevant thinking which is crucial for attitude formulation. Some organizations rely on peripheral cues with low elaboration to encourage an immediate purchase. However, through the theory of persuasion and ELM we may understand that attracting customers through high elaboration is better for companies as a means of encouraging meaningful purchases and retaining customer loyalty. As attitude change is achieved through the central route with high elaboration (usually enduring and resistant to change), it is beneficial for companies seeking to encourage high engagement with customers, and generate repurchase. Thirdly, similar to education tourism, the quality of the message needs to be very carefully managed, as strong arguments are likely to invoke favorable impression of the product. However, managing bad messages is equally important. While the strong nature of a message can benefit organizations, a negative message may also be spread virally in cyberspace through the ability of technology to provide instantaneous and anonymous communication.

This research has two main limitations that could be addressed in future studies. First, while the study examined argument quality and source credibility as a whole, each of these variables has several sub-dimensions. For example, the sub-dimensions of argument quality are accuracy and timeliness, and, for source credibility, expertise and trustworthiness. Future studies might determine the impacts of each dimension, and therefore a systematic process of the persuasion process could be determined. Second, this study is the first to combine two main types of social media, BBS and blog, into one experiment. However, every social media platform has different interactive modes and its own influence on marketing eWOM. Comparisons of various channels and their impacts on third-party marketing strategies could be addressed in future studies, by understanding various social media channels and their impacts on marketing strategies, it can help to provide insights into how individual organization might use social media that best fits their objectives. 


\section{REFERENCES}

Alreck, P. L., \& Settle, R. B. (1985). The Survey Research Handbook. Homewood, Ill.: R.D Irwin.

Baker, M. (2001). Selecting a research methodology. The Marketing Review, 1, 373-397.

Bettinghaus, E. P., \& Cody, M. J. (Eds.). (1987). Persuasive Communication (4th ed.). New York: Holt Rinehart \& Winston.

Bhattacherjee, A., \& Sanford, C. (2006). Influence processes for information technology acceptance: An elaboration likelihood model. MIS Quarterly, 30(4), 805-825.

Boone, L. E., \& Kurtz, D. L. (2007).Contemporary Marketing: 13th edition. Mason, OH: Thomson/South-Western.

Campbell, D. T., \& Stanley, J. C. (1966). Experimental and quasi-experimental design for research. Chicago: Rand McNally.

Chan, N. L., \& Guillet, B. D. (2011). Investigation of social media marketing: how does the hotel industry in Hong Kong perform in marketing on social media websites? Journal of Travel \& Tourism Marketing, 28(4), 345-368.

Chaiken, S. (1980). Heuristic versus systematic information processing and the use of source versus message cues in persuasion. Journal of Personality and Social Psychology, 39(5), 752766.

Chaiken, S., \& Eagly, A. H. (1976). Communication modality as a determinant of message persuasiveness and message comprehensibility. Journal of Personality and Social Psychology, 34, 606-614.

Cheung, M. K., Lee, K. O., \& Rabjohn, N. (2008). The impact of electronic word-of-mouth. Internet Research, 18(3), 229-247.

Cheung, M. K., \& Thadani, R. (2010).The effectiveness of electronic Word-of-Mouth communication: a literature analysis. Paper presented at the 23rd Beld eConference - eTrust: Implications for the individual, Enterprises and Society, Bled, Slovenia.

Choi, S., \& Rifon, N. (2002). Antecedents and consequences of web advertising credibility: a study of consumer response to banner ads. Journal of Interactive Advertising, 3(1), 12-24. 
Chu, S., \& Kamal, S. (2008). The effect of perceived blogger credibility and argument quality on message elaboration and brand attitudes: an exploratory study. Journal of Interactive Advertising, 8(2), 26-37.

Chung, J. Y., \& Buhalis, D. (2008).A study of Online Travel Community and Web 2.0: Factors Affecting Participation and Attitude. Paper presented at the ENTER2008, Innsbruck.

Coakes, S. J., Steed, L., \& Price, J. (2008). SPSS: analysis without anguish: version 15.0 for Windows. Milton, Qld: John Wiley \& Sons, Australia.

Coulter, K., \& Punj, G. (2004). The effects of cognitive resource requirements, availability, and argument quality on brand attitudes: a melding of elaboration likelihood and cognitive resource matching theories. Journal of Advertising, 33(4), 53-64.

Crampton, T. (2011). Social media in China: the same, but different. China Business Review. US-China Business Council. Retrieved from http://www.thomascrampton.com/china/socialmedia-china-business-review/

Crompvoets, J., Rajabifard, A., Bregt, A., \& Williamson, I. (2004). Assessing the worldwide developments of national spatial data clearing houses. International Journal of Geographical Information Science, 18(7), 193-218.

Dasgupta, S., Granger, M., \& Mcgarry, N. (2002). User acceptance of E-collaborative technology: An extension of the technology acceptance model. Group Decision and Negotiation, $11,87-100$.

Davy, C. (2006). Recipients: the key to information transfer. Knowledge Management Research \& Practice, 4(1), 17-25.

DeLone, W. H., \& McLean, E. R. (2003). The DeLone and McLean model of information systems success: a ten-year update. Journal of Management Information Systems, 19(4), 9-30.

Douglas, S. C., Kiewitz, C., Martinko, M. J., Harvey, P., Kim, Y., \& Chun, J. U. (2008). Cognition, emotions, and evaluation: an elaboration likelihood model for workplace aggression. Academy of Management Review, 33(2), 425-451.

Eagly, A. H., \& Chaiken, S. (1993). Psychology of Attitudes. Fort Worth, TX: Harcourt Brace Jovanovich. 
Flynn, B. S., Worden, J. K., Bunn, J. Y., Connolly, S. W., \& Dorwaldt, A. L. (2011). Evaluation of smoking prevention television message based on the elaboration likelihood model. Health Education Research, 26(6), 976-987.

Gillin, P. (2007).The New Influencers: A Marketer's Guide to the New Social Media. Sanger, CA: Quill Driver Books.

Ham, S. H., Weiler, B., Hughes, M., Brown, T., Curtis, J., \& Poll, M. (2008). Asking Visitors to Help: Research to Guide Strategic Communication for Protected Area Management. Gold Coast: CRC for Sustainable Tourism.

Hong, T. (2006). The influence of structural and message features on web site credibility. Journal of the American Society for Information Science and Technology, 57(1), 114-127.

Hsu, C. L., \& Lin, J. C. (2008). Acceptance of blog usages: The roles of technology acceptance, social influence and knowledge sharing motivation. Information \& Management, 45, 65-74.

Kaplan, A. M., \& Haenlein, M. (2010). Users of the word, unite! The challenges and opportunities of social media. Business Horizons, 53, 59-68.

Ko, D. G., Kirsch, L., \& King, W. R. (2005). Antecedents of knowledge transfer from consultants to clients in enterprise system implementations. MIS Quarterly, 29(1), 59-85.

Kumar, R. (2010). Research Methodology. London: SAGE Publications Ltd.

Larson, C. U. (2010). Persuasion: Reception and Responsibility. Belmont: Thomson.

Lee, H., Law, R., \& Murphy, J. (2011). Helpful reviewers in TripAdvisor, an online travel community. Journal of Travel \& Tourism Marketing, 28(7), 675-688.

Li, C., \& Bernoff, J. (2008).Groundswell: Winning in a World Transformed by Social Technologies. Boston: Harvard Business Press.

MacKenzie, S., \& Lutz, R. (1989). An Empirical Examination of the Structural Antecedents of Attitude Toward the ad in an advertising pretesting context. Journal of Marketing, 53, 48-65.

Mangold, W. G., \& Faulds, D. J. (2009). Social media: The new hybrid element of the promotion mix. Business Horizons, 52, 357-365. 
Morris, J. D., Woo, C., \& Singh, A. J. (2005). Elaboration likelihood model: A missing intrinsic emotional implication. Journal of Targeting, Measurement and Analysis for Marketing, 14(1), 79-98.

Negash, S., Ryan, T., \& Igbaria, M. (2002). Quality and effectiveness in web-based customer support systems. Information\& Management, 40(8), 757-768.

Nussbaum, R. E. (2006). Sexual Orientation and Homophobia in the Elaboration Likelihood Model. Doctorate of Philosophy, University of Hawaii, Manoa.

O'Connor, P. (2008). User-generated content and travel: A case study on TripAdvisor (47-58) Information and Communication Technologies in Tourism. New York: Springer Wien,

O'keefe, D. (Ed.). (2002). Persuasion: Theory \& Research. Thousand Oaks: Sage Publications.

Park, C., Lee, J., \& Han, I. (2007). The effect of on-line consumer reviews on consumer purchase. International Journal of Electronic Commerce, 11(4), 125-148.

Perloff, R. M. (Ed.). (2003). Processing persuasive communications: Elaboration likelihood Model. The Dynamics of Persuasion. London: Lawrence Erlbaum Associates: 119-136.

Petty, R. E., Cacioppo, J. T., \& Schumann, D. (1983). Central and peripheral routes to advertising effectiveness: The moderating role of involvement. Journal of Consumer Research, 10, 135-146.

Petty, R. E., \& Cacioppo, J. T. (1986).Communication and persuasion: Central and Peripheral Routes to Attitude Change. New York: Springer-Verlag.

Petty, R. E., \& Krosnick, J. (Eds.). (1995). Attitude strength: Antecedents and Consequences. Mahwam, NJ: Lawrence Erlbaum.

Priester, J., \&Petty, R. (1995).Source attribution and persuasion: perceived honesty as a determinant of message scrutiny. Personality and Social Psychology Bulletin, 21(6), 637-654.

Priester, J., \& Petty, R. (2003).The influence of spokesperson trustworthiness on message elaboration, attitude strength and advertising effectiveness. Journal of Consumer Psychology, 13(4), 408-421. 
Ramsey, G. (2006). Digital marketing strategies in the age of consumer control. Retrieved from http://www.asc.upenn.edu/courses/comm530/secure/Fall\%202006/Digital\%20Marketing\%20Str ategies.pdf

Ritchie, B. W., Carr, N., \& Cooper, C. P. (2003). Managing educational tourism. Portland: Channel View Publications.

Rodgers, S., \& Sheldon, K. M. (2002). An improved way to characterize internet users. Journal of Advertising Research, 42(5), 85-95.

Singh, T., Verson-Jackson, L., \& Cullinane, J. (2008). Blogging: A new play in your marketing game plan. Business Horizons, 51(4), 281-292.

Song, I. (2008). Interactivity and Political Attitude Formation: The Elaboration Likelihood Model of Interactive Media. Doctorate of Philosophy, Indiana University.

Sundar, S. S., Knobloch-Westerwick, S., \& Hastall, M. R. (2007). News cues: information scent and cognitive heuristics. Journal of American Society for Information Technology, 58(3), 366378.

Sussman, S.W., \& Siegal, W.S. (2003). Informational influence in organizations: an integrated approach to knowledge adoption. Informational Systems Research, 14(1), 47-65.

Tam, K. Y., \& Ho, S. Y. (2005). Web personalization as a persuasion strategy: an Elaboration Likelihood Model perspective. Information Systems Research, 16(3), 271-291.

Tang, L., Jang, S., \& Morrison, A. (2012). Dual-route communication of destination websites. Tourism Management, 33(1), 38-49.

Wang, Y., \& Fesenmaier, D. R. (2004a). Modeling participation in an online travel community. Journal of Travel Research, 25(6), 261-270.

Wang, Y., \& Fesenmaier, D. R. (2004b). Towards understanding members' general participation in and active contribution to an online community. Tourism Management, 25(6), 709-722.

Wang, B., \& Li, S. (2008). Education tourism market in China: an explorative study in Dalian. International Journal of Business and Management. 5(3), 44-49. 
Wood, W., \& Kallgren, C. A. (1988). Communicator attributes and persuasion: Recipients' access to attitude-relevant information in memory. Personality and Social Psychology Bulletin, 14, 172-182.

Wrong, D. H. (1979). Power, its Forms, Bases, and Uses. New York: Harper and Row Publishers.

Yang, S., Hung, W., Sung, K., \& Farn, C. (2006). Investigating initial trust toward e-tailors from the elaboration likelihood model perspective. Psychology\& Marketing, 23(5), 429-445.

Zhang, W., \& Watts, S. (2003). Knowledge Adoption in Online Communities of Practice. Paper presented at the 24th Annual International Conference on Information Systems, Seattle, Washington, DC.

Zhu, J., \& Tan, B. (2007).Effectiveness of Blog Advertising: Impact of Communicator Expertise, Advertising Intent and Product Involvement. ICIS 2007 Proceedings. Paper 121. 
Tables and Figures

Table 1: Definitions of persuasion

\begin{tabular}{l}
$\begin{array}{l}\text { A communication process in which the communicator seeks to } \\
\text { elicit a desired response from his receiver. }\end{array}$ \\
\hline $\begin{array}{l}\text { A symbolic activity whose purpose is to affect the } \\
\text { internalization or voluntary acceptance of new cognitive states } \\
\text { or patterns of overt behavior through the exchange of messages. }\end{array}$ \\
\hline $\begin{array}{l}\text { A conscious attempt by one individual to change the attitudes, } \\
\text { beliefs, or behavior of another individual or group of } \\
\text { individuals through the transmission of some message. }\end{array}$ \\
\hline $\begin{array}{l}\text { A successful intention effort at influencing another's mental } \\
\text { state through communication in a circumstance in which the } \\
\text { persuadee has some measure of freedom. }\end{array}$ \\
\hline $\begin{array}{l}\text { A symbolic process in which communicators try to convince } \\
\text { other people to change their attitudes or behavior regarding an } \\
\text { issue through the transmission of a message, in an atmosphere } \\
\text { of free choice. }\end{array}$
\end{tabular}

Table2: Treatments

\begin{tabular}{|c|c|c|}
\hline Treatment & Level of SC & Level of AQ \\
\hline 1 & High & High \\
\hline 2 & High & Low \\
\hline 3 & Low & High \\
\hline 4 & Low & Low \\
\hline
\end{tabular}


Table 3: Operationalization of concepts and scales

\begin{tabular}{|c|c|c|}
\hline Concept & Operationalization & Data required \\
\hline $\begin{array}{l}\text { Source } \\
\text { credibility } \\
\text { (Independent } \\
\text { variable) }\end{array}$ & $\begin{array}{l}\text { Information } \\
\text { willingness to pender's } \\
\text { information in a manner that } \\
\text { indicates honesty, fairness, } \\
\text { sincerity, and expertise (Choi } \\
\text { \&Rifon, 2002; Priester\& Petty, } \\
\text { 1995, 2003) }\end{array}$ & $\begin{array}{l}\text { Four-item, seven-point semantic } \\
\text { differential scale "trustworthy /not", } \\
\text { "reputable/not”, “experienced/not”, } \\
\text { "expertise/not” }\end{array}$ \\
\hline $\begin{array}{l}\text { Argument } \\
\text { quality } \\
\text { (Independent } \\
\text { variable) }\end{array}$ & $\begin{array}{lr}\text { Strong: } & \text { brand-related } \\
\text { information } & \text { generate positive } \\
\text { elaboration } & \\
\text { Weak: } & \text { brand-related } \\
\text { information } & \text { generate negative } \\
\text { elaboration } \quad \text { (Coulter \&Punj, } \\
\text { 2004; Petty \& Cacioppo, 1986) }\end{array}$ & $\begin{array}{l}\text { Four-item, seven-point semantic } \\
\text { differential scale "relevant/not", } \\
\text { "convincing/not”, "pleasant/not”, } \\
\text { "useful/not” }\end{array}$ \\
\hline $\begin{array}{l}\text { Perceived } \\
\text { destination } \\
\text { attractiveness } \\
\text { (dependent } \\
\text { variable) }\end{array}$ & $\begin{array}{l}\text { 1. Attitudes toward the } \\
\text { destination (MacKenzie \& } \\
\text { Lutz, 1989) }\end{array}$ & $\begin{array}{l}\text { 1. Five-item, seven-point semantic } \\
\text { differential scale, "good/not", } \\
\text { "attractive/not”, "intent to go/not", } \\
\text { "favorable/unfavorable”, "bad/not" }\end{array}$ \\
\hline
\end{tabular}

Sources. Choi and Rifon (2002); Coulter and Punj (2004); MacKenzie and Luts (1989); Petty and Cacioppo (1986); Priester and Petty (1995, 2003).

Table 4: Comparison of websites with strong and weak source credibility

\begin{tabular}{|l|l|}
\hline Strong & Weak \\
\hline Recognized logo -TigTag & Personal logo \\
\hline Established since 1998 & Just opened 2 months \\
\hline Professional study immigration website & Personal blog \\
\hline
\end{tabular}




\begin{tabular}{|c|c|}
\hline (non-commercial) & \\
\hline $\begin{array}{l}\text { Aimed at providing users with various } \\
\text { types of overseas information }\end{array}$ & $\begin{array}{l}\text { A platform to share personal opinions and } \\
\text { experience }\end{array}$ \\
\hline $\begin{array}{l}\text { Content are objective and accurate, } \\
\text { comprehensive and timely }\end{array}$ & $\begin{array}{l}\text { Content are randomly posted, no set } \\
\text { structure or timeliness }\end{array}$ \\
\hline Most popular overseas community & Not well-known \\
\hline $\begin{array}{l}\text { Friendly and harmonious atmosphere } \\
\text { provide users with an important } \\
\text { platform for mutual help and exchange }\end{array}$ & $\begin{array}{l}\text { Can only be accessed by certain people } \\
\text { who know the answer to the entry } \\
\text { question }\end{array}$ \\
\hline More than 350,000 registered users & Has 40 friends \\
\hline $\begin{array}{l}\text { Website page views is } 1,550,000 \text { pages / } \\
\text { day }\end{array}$ & Website page views is 4 pages / day \\
\hline $\begin{array}{l}\text { Unique users views is } 47,000 \text { people / } \\
\text { day }\end{array}$ & Unique users views is 1-2 people / day \\
\hline $\begin{array}{l}\text { Vast majority of Tigtag network users } \\
\text { are people going abroad or relevant } \\
\text { groups with clear common needs }\end{array}$ & $\begin{array}{l}\text { Majority of viewers are people who know } \\
\text { her }\end{array}$ \\
\hline $\begin{array}{l}\text { Good loyalty and high credibility with } \\
\text { users }\end{array}$ & $\begin{array}{l}\text { Low loyalty and low credibility with } \\
\text { viewers }\end{array}$ \\
\hline
\end{tabular}


Table 5: Comparison of information sender with strong and weak source credibility

\begin{tabular}{|l|l|}
\hline Strong & Weak \\
\hline Verified identity by TigTag & No verification for identity \\
\hline $\begin{array}{l}\text { President of 'study aboard' education } \\
\text { consultancy company }\end{array}$ & Current high school student in China \\
\hline Graduated from Yale University & n/a \\
\hline $\begin{array}{l}14 \quad \text { years' experience in overseas } \\
\text { education }\end{array}$ & Has never been to Country A \\
\hline $\begin{array}{l}\text { Picture - } \\
\text { mid-aged } \\
\text { male }\end{array}$ & $\begin{array}{l}\text { gicture - } \\
\text { girl year old }\end{array}$ \\
\hline $\begin{array}{l}\text { CCTV "Taiwan business story", } \\
\text { "Chinese World" special reports figures; } \\
\text { Pioneer of the China overseas education, } \\
\text { as best study aboard planner of the industry; }\end{array}$ & ny millions of capital residents \\
\hline
\end{tabular}


Table 6: Description of country A with strong and weak argument quality

\section{Strong}

(Scenario) Consider yourself to be in the process of choosing an overseas study destination. Based on the following description of Country A, you will have a favorable impression towards the country and intend to go there to study:

Main content covered in the description and pictures shown:

Country background (well-developed country),Climate (enjoyable), population (15 million), education quality (world-class education), cultural background (multi-cultural)
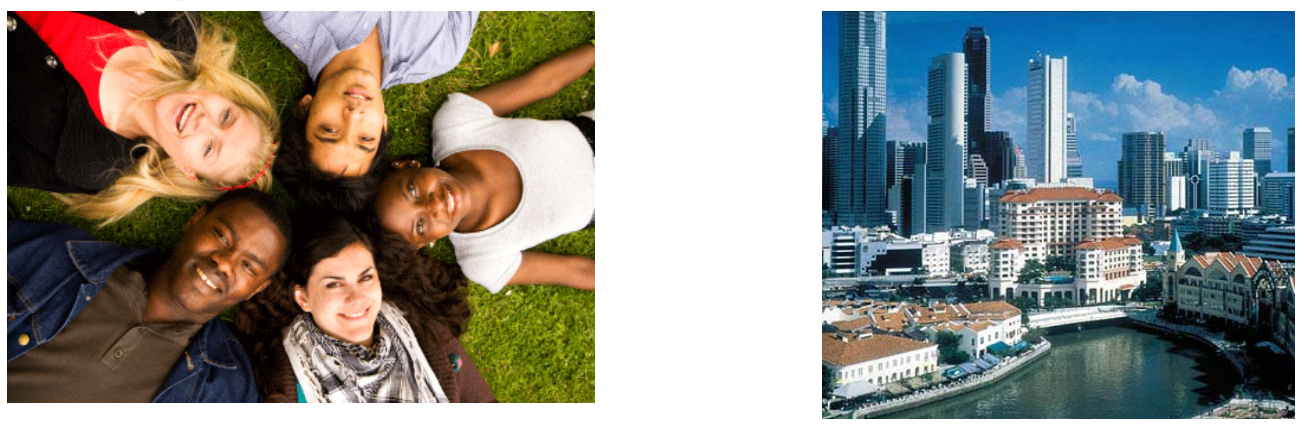

Weak

(Scenario) Consider yourself to be in the process of choosing a overseas study destination. Based on the following description of Country A, you will have favorable impression towards the country and intend to go there to study:

Main content covered in the description and pictures shown:

Country background (developing country) Climate (distinctive four seasons), population (0.5 billion), education quality (ordinary education), cultural background (95\% of the population are local residents)
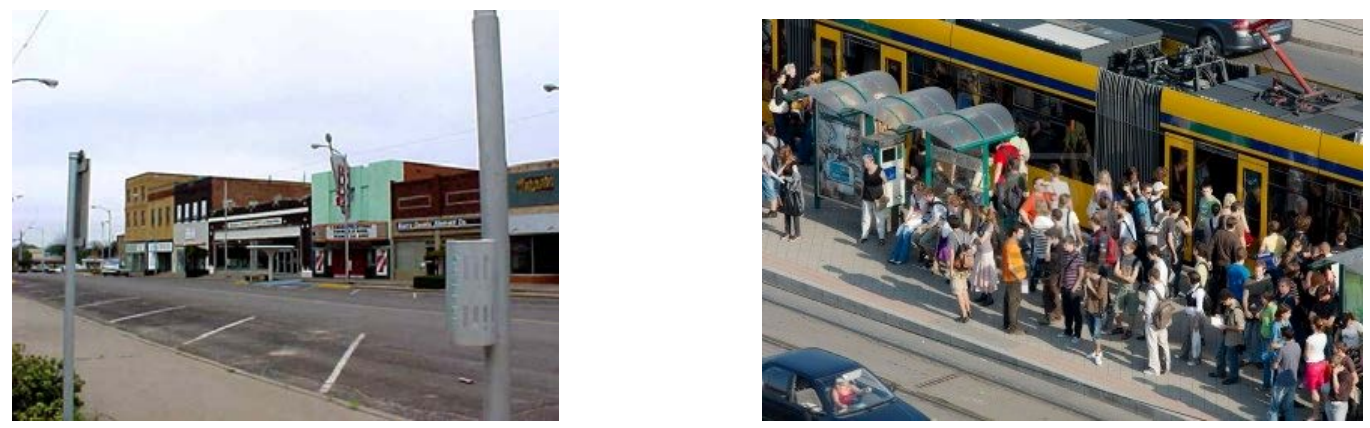
Table 7: Comparison of the means of SC total, AQ total, DA total

\begin{tabular}{|c|c|c|c|}
\hline Treatment & $\begin{array}{c}\text { SC total } \\
\text { Mean }\end{array}$ & $\begin{array}{c}\text { AQ total } \\
\text { Mean }\end{array}$ & $\begin{array}{c}\text { DA total } \\
\text { Mean }\end{array}$ \\
\hline HscHaq & 17.97 & 17.40 & 23.16 \\
\hline HscLaq & 16.71 & 14.57 & 15.98 \\
\hline LscHaq & 13.36 & 16.81 & 23.10 \\
\hline LscLaq & 12.79 & 13.47 & 16.64 \\
\hline
\end{tabular}

Table 8: ANOVA results of $2 \times 2$ experiment

Dependent Variable: DA Total

\begin{tabular}{|l|r|r|r|r|}
\hline Source & df & Mean Square & F & \multicolumn{1}{|c|}{ Sig. } \\
\hline SC & 1 & 8.728 & .308 & .579 \\
\hline AQ & 1 & 2724.246 & 96.242 & .000 \\
\hline SC * AQ & 1 & 4.142 & .146 & .702 \\
\hline
\end{tabular}

a. R Squared $=.298$ (Adjusted R Squared $=.289$ )

Table 9: Correlation: SC total and DA total

\begin{tabular}{|c|c|c|c|}
\hline \multirow{2}{*}{ SC Total } & Pearson Correlation & 1 & DA Total \\
\cline { 2 - 4 } & Sig. (2-tailed) & & $.264^{* *}$ \\
\cline { 2 - 4 } & $\mathrm{N}$ & 235 & .000 \\
\hline \multirow{2}{*}{ DA Total } & Pearson Correlation & $.264^{* *}$ & 233 \\
\cline { 2 - 4 } & Sig. (2-tailed) & .000 & 1 \\
\cline { 2 - 4 } & $\mathrm{N}$ & 233 & 233 \\
\hline
\end{tabular}


Table 10: Correlation: AQ total and DA total

\begin{tabular}{|c|c|c|c|}
\hline \multicolumn{2}{|c|}{} & DA Total & AQ Total \\
\hline \multirow{3}{*}{ DA Total } & Pearson Correlation & 1 & $.731^{* *}$ \\
\cline { 2 - 4 } & Sig. (2-tailed) & & .000 \\
\cline { 2 - 4 } & $\mathrm{N}$ & 233 & 233 \\
\hline \multirow{3}{*}{ AQ Total } & Pearson Correlation & $.731^{* *}$ & 1 \\
\cline { 2 - 4 } & Sig. (2-tailed) & .000 & \\
\cline { 2 - 4 } & $\mathrm{N}$ & 233 & 235 \\
\hline
\end{tabular}




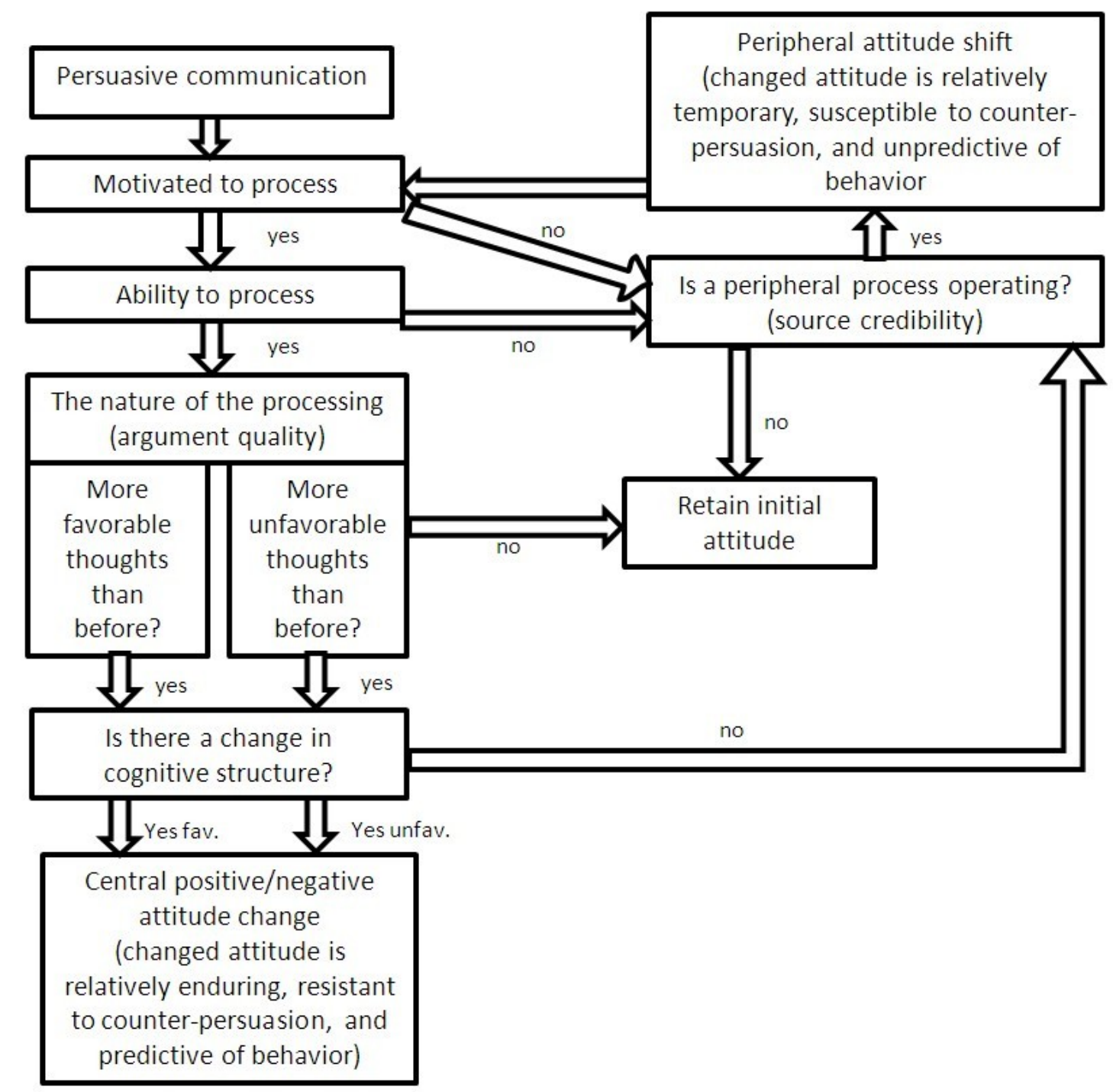

Figure 1: Elaboration likelihood model

Source. Petty and Cacioppo (1986) 


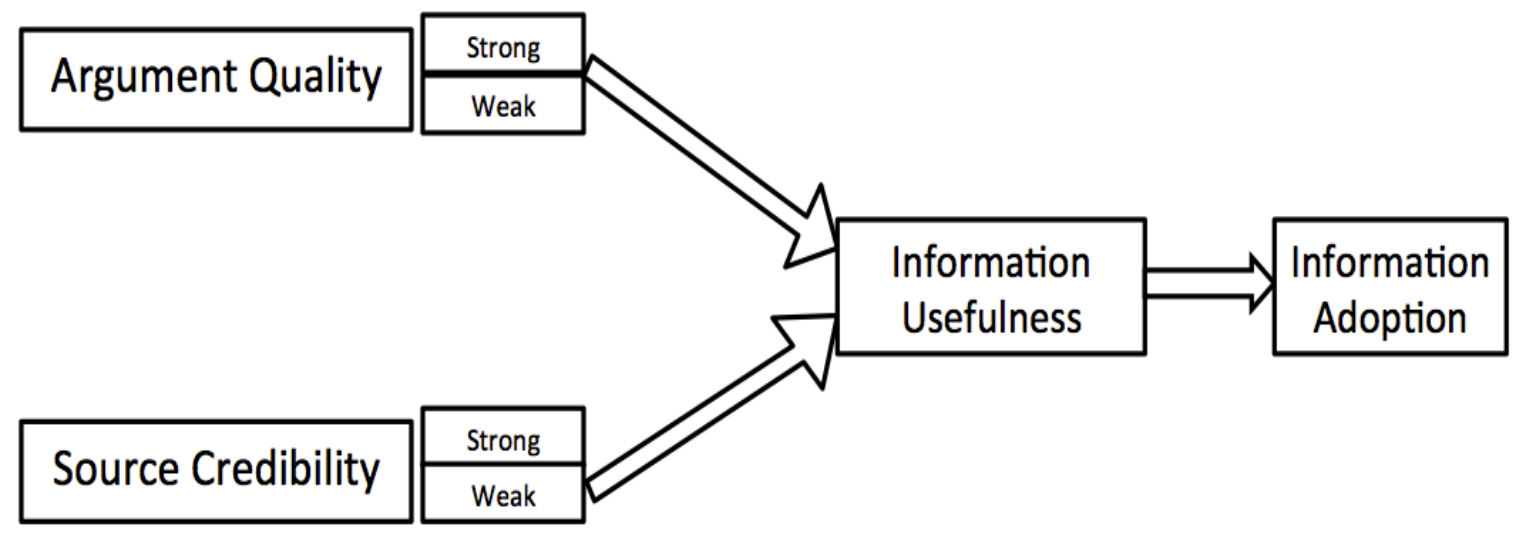

Figure 2: Information adoption model (conceptual framework)

Source. Sussman and Siegal (2003).
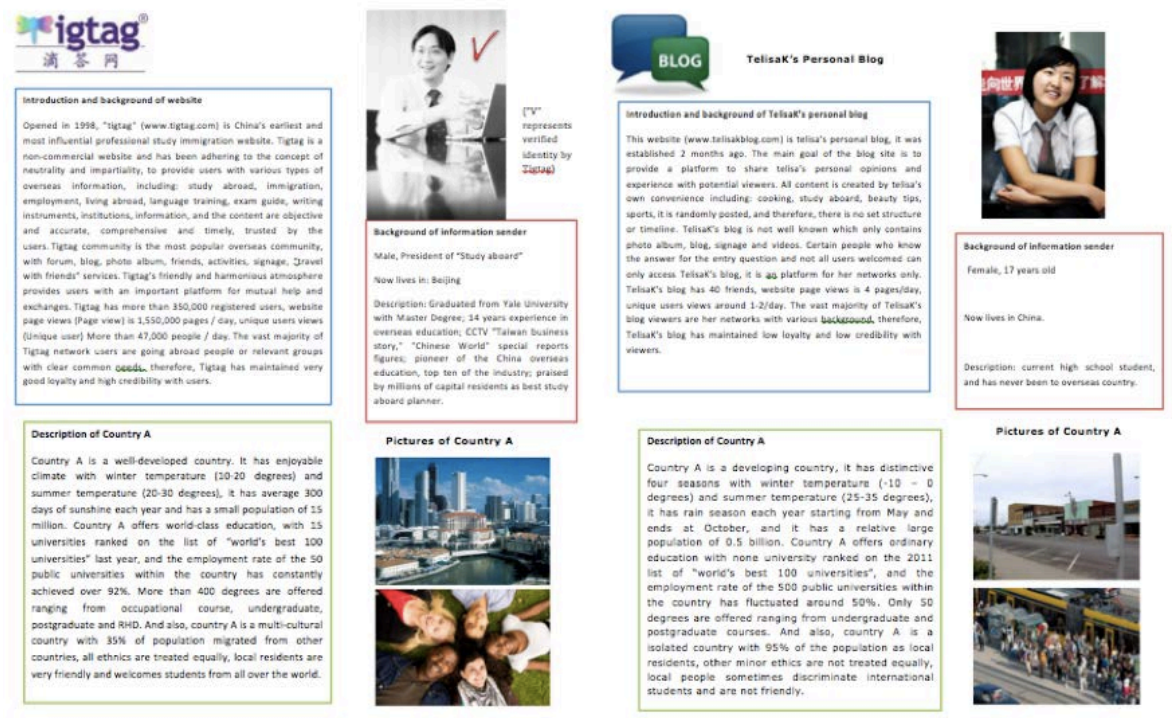

Figure 3: Stimulus material 


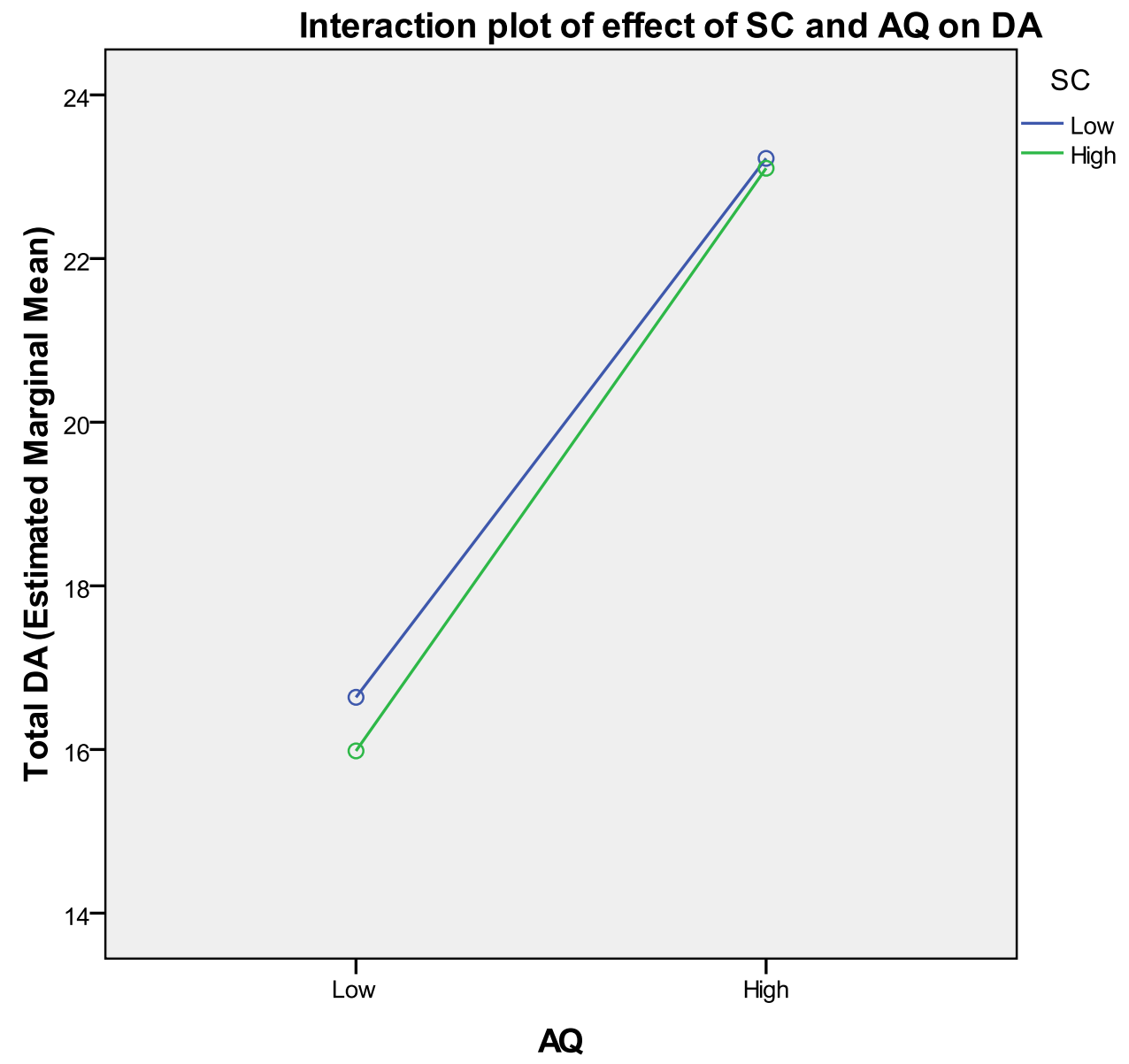

Figure 4: Source credibility $\times$ Argument quality interaction effects 